\title{
Determinants of Capital Structure in Bahrain Stock Market
}

\author{
Abdelrhman Ahmad Meero \\ Finance and Accounting Department, College of Business Administration, Kingdom \\ University, Kingdom of Bahrain
}

Tel: 973-1-3300920 E-mail: a.meero@ku.edu.bh

Received: Nov. 23, 2016

Accepted: Dec. 12, 2016

Published: Dec. 21, 2016

doi:10.5296/ifb.v3i2.10351

URL: http://dx.doi.org/10.5296/ifb.v3i2.10351

\begin{abstract}
The aim of this paper is to examine the determinants of capital structure (profitability, size, risk and growth). The sample is composed of 39 Bahraini firms listed in Bahrain Stock Market. The study covered the period 2011-2015. Correlation and regression analysis have been used to identify the relationship between the capital structure determinants and debt leverages (book leverage and market leverage). Correlation analysis aims to identify this relationship at market level and at sectorial level. Regression analysis objective is to anticipate the models characterizing the relationships between determinants and capital leverages. Results of the analysis shows negative significant relationship between profitability and dependent variables, with more significance relationship with market leverage. This relationship is demonstrated in market level and in insurance and services sectors between profitability and book leverage. When the market leverage is the dependent variable this relationship is valid in market level and in banking, hotels, insurance and services sectors. Positive significant relationship has been found between size and both leverages in market level. Similar result is detected on sectorial level in banking, industrial, investment and services when the dependent variable is book leverage. Size-market leverage relationship is positive and significant also in insurance, investment and services sectors. The relationship risk - book leverage is significant only on sectorial level in Industrial, insurance and investment sectors. In term of market leverage - risk relationship, significant relationship is detected in market level and in investment and services sectors. Regression analysis results present a significant linear model reflecting the relationship between determinants of capital structure and leverages.
\end{abstract}

Keywords: Bahrain Bourse Stock Market, Capital structure, Book leverage, Market leverage Profitability, Firm size, Risk, Growth, Book leverage, Market leverage 


\section{Introduction}

Capital structure puzzle is widely discussed and tested in the literature review. The question of optimal capital structure is one of the most research topics treated in the fields of modern corporate finance and corporate governance. Despite the existence of theoretical background and models, as well as the results of important empirical researches, but capital structure selection and factors affecting this decision still controversial issue. Earlier effort given by Modigliani \& Miller (1958) and the extensive work of the successors couldn't give a clear answer about factors affecting capital structure and the combination of debt and equity in the capital structure (Rajan \& Zingales, 1995; Gill et al., 2011). Firm's management still consider capital structure decision as one of the strategic decisions, which affects the cost of debt and maximize the shareholders' wealth (Block \& Hirt, 1994; Bain \& Band, 2016).

Despite the huge literature related to the capital structure determining factors and capital structure choices in developed countries, it is still at earlier stage in the developing countries like Bahrain and other Gulf countries. For that reason, this paper endeavors to inspect the determinants of capital structure (profitability, size, risk and growth) of a sample of 39 Bahraini firms listed in Bahrain Bourse (stock market) over the period 2011-2015. This study is the first study examining the capital structure determinant in Bahrain Stock market. All the sectors of stock market are covered by the study: Banking, Hotels \& Tourism, Industrial, Insurance, Investment, Services. Financial analysis has been done to the financial statements of the sample by using Microsoft Excel 2010. The Statistical Package for the Social Sciences (SPSS 16.0) has been used to identify the relationship between the dependent and the independent variables.

Following this introduction, the rest of the paper is structured as follows. Literature review of the research is presented in section (2). Formulating the Research Hypothesis and Null Hypothesis detailed in section (3). In section (4), the sample of the study is presented. Data collection and research Methodology are presented in section (5). Research models are developed in section (6). Findings of the empirical results and hypotheses experimentation are discussed in section (7). Finally, section (8) is assigned to the concluding remarks of the study.

\section{Literature Review}

Several studies on capital structure determinants have been published in the related literature. The theoretical framework of capital structure theory was presented first by Modigliani \& Miller (1958). In their theory, Modigliani \& Miller (MM) proved that under the hypotheses of perfect capital markets, no taxes, no bankruptcy, no transaction costs, the firm value is independent of its capital structure. According to MM, debt-to-equity ratio has no impact on the total value of firm. Based on MM theory, the two main theories of capital structure were developed, which are the trade-off theory (Kraus \& Litzenberger, 1973; Myers, 1977) and the pecking-order theory (Myers \& Majluf, 1984; Myers, 1984).

\subsection{Trade-off Theory}

As per Myers (1984) trade-off theory is the balance between tax savings from debt and 
deadweight bankruptcy costs. According to this theory, capital structure choices are determined by a trade-off between the benefits and costs of debt (Kraus \& Litzenberger, 1973). As explained by many researchers, optimal capital structure of organizations involves the tradeoff among the bankruptcy costs and agency costs, the effects of corporate and personal taxes (Jensen \& Meckling, 1976), bankruptcy costs, tax benefits, and agency costs related to asset substitution (Myers, 1977), and overinvestment (Jensen, 1986; Stulz, 1990). The trade-off hypothesis assumes a positive relationship between profitability and leverage because low profitability may increase bankruptcy risk (Kayo \& Kimura, 2011).

\subsection{Pecking Order}

Founders of the pecking order theory Myers \& Majluf (1984) and Myers (1984) assume that firms issue first internal funds, debt, and then equity. The pecking order theory is based on the information asymmetries, which exist between insiders and outsiders of the firm (management and investors). There is no concept of target capital structure for a firm in the pecking order theory, which exists in the trade-off theory (Dang, 2013). Per reference to the pecking order theory, firms with higher profitability will prefer internal financing to debt and therefore a negative relationship is expected between profitability and capital leverage (Fama \& French, 2002; Delcoure, 2007; Daskalakis \& Psillaki, 2008; Chakraborty, 2010; Kayo \& Kimura, 2011; Joeveer, 2013; Chakraborty, 2013; Dang, 2013; Meero, 2015).

Several empirical research results support the negative relationship between capital structure and firm's performance like the research of Barton et al. (1989); Michael, Chittenden, \& Poutziouris (1999); Mishra \& McConaughty (1999); Jordan, Lowe, \& Taylor (1998); Chittenden, Hall, \& Hutchinson (1996). They support a negative relationship between profitability and capital structure. This conclusion is also has been found by Titman \& Wessels (1988); Rajan \& Zingales (1995) who find strong negative relationships between debt ratios and past profitability. Jensen, Solberg, \& Zorn (1992) and Li (2010) find also a negative relationship between the business performance and debt ratio.

\subsection{The Factors Affecting the Capital Structure}

Literature review related to determinants of capital structure shows variety of variables that have been used to identify this relationship. Profitability, size and growth almost have been used as independent variables in the study of Chen (2004); Hijazi \& Tariq (2006); Frank \& Goyal (2009); Chhapra \& Asim (2012); Khrawish \& Khraiwesh (2010); Sbeiti (2010); Afza \& Hussain (2011); Baharuddin et al. (2011); Abdul Wahab et al. (2012); Pahuja \& Sahi (2012); Maxwell \& Kehinde (2012); Mokhova \& Zinecker (2013); Ghazouani (2013); Qayyum (2013); Fauzi et al. (2013); Awan \& Amin (2014); AbWahab \& Ramli (2014); Handoo \& Sharma (2014); Huang \& Shen (2015); Meero (2015); Naim Nasimi (2016).

Some studies also focused on the risk as independent variable determining the capital structure of the firm. For example of these studies, the research of Hsia (1981); Demsetz \& Lehn (1985); Titman \& Wessels (1988); Booth, Aivazian, DemirgucKunt, \& Maksimovic (2001); Chen (2004), Buferna et al. (2005); Huang \& Song (2006); Ghazouani (2013); Naim Nasimi (2016). In addition to profitability, size, growth and risk, some studies have tested the 
effect of another variables on capital structure like: tangible and intangible assets (Rajan \& Zingales, 1995), liquidity (Strebulaev, 2007), cost of debt (Jensen \& Meckling, 1976), tax rate (Sibilkov, 2009), depreciation (Teker et al., 2009). For the current study, profitability, size, growth and risk will be considered as independent variables and book leverage and market leverage as dependent variables.

\subsubsection{Profitability}

There is no obvious result explaining the effect of profitability on the capital structure. Contradictory theoretical and practical predictions on the effects of profitability on leverage have been found. As it has been explained, following the pecking-order theory, profitable firms, which have access to retained profits, can use these resources for firm financing rather than outside sources. Per reference to the Trade-off theory, more profitable firms are exposed to lower risks of bankruptcy and have greater incentive to employ debt to exploit interest tax shields. (Jensen, 1986) predicts under certain conditions a positive relationship between profitability and financial leverage. Most empirical studies observe a negative relationship between leverage and profitability (Kester, 1986; Titman \& Wessels, 1988; Friend \& Lang, 1988; Rajan \& Zingales, 1995; Booth, Aivazian, DemirgucKunt, \& Maksimovic, 2001; Fama \& French, 2002; Huang \& Song, 2002; Delcoure, 2007; Daskalakis \& Psillaki, 2008; Karadeniz et al., 2009; Chakraborty, 2010; Kayo \& Kimura, 2011; Joeveer, 2013; Chakraborty, 2013; Dang, 2013).

\subsubsection{Firm Size}

Pecking order theory with trade off theory pretend positive and also negative relationship between the organizational leverage and its size. Empirically, certain results find that size of the firm has positive impacts on its leverage like the results of Titman \& Wessels (1988); Rathinasamy, Krishnaswamy, \& Mantripragada (2000); Huang \& song (2006). In the other side negative relationship between size and leverage of the firm has been found by Rajan \& Zingales (1995); Shah \& Khan (2007); Hernádi \& Ormos (2012).

\subsubsection{Firm Risk}

Optimal capital structure of the firm could be obtained at a lower level of volatility of firm's earnings according to the results of Demsetz \& Lehn (1985); Titman \& Wessels (1988); Booth et al. (2001). Standard deviation of the return on equity used as a proxy for business risk.

\subsubsection{Growth of Sales (revenues)}

Reference to pecking order theory high growth firms prefer debts than outside equity financing (Myers \& Majluf, 1984). Contrariwise, some empirical studies pretend that growth of the firm increases in the agency costs of debt and to a reduction in the agency costs of managerial discretion which may indirectly affect negatively the financial leverage (Titman, \& Wessels, 1988; Smith, \& Watts, 1992; Booth, Aivazian, DemirgucKunt, \& Maksimovic, 2001; Goyal, \& Racic, 2002). 


\section{Macrothink

\section{The Hypotheses of the Study}

As it was presented in the literature review previously discussed, such subject is still a disputable in the capital structure and corporate governance area. This study focuses on the determinants of capital structure in Bahrain Bourse (stock market). The dependent variables representing capital structure are book leverage and market leverage. The independent variables are profitability, size, growth and risk. These variables have been measured as per following equations:

\section{Dependent variables:}

1) Book leverage

$$
\text { Booklev }=\frac{\text { total liabilities }}{\text { book value }(\text { debt }+ \text { equity })}
$$

2) Market leverage

$$
\text { Marktlev }=\frac{\text { total liabilities }}{\text { market value of equity }+ \text { total liabilities }}
$$

\section{Independent variables}

1) Profitability

Net Income as percentage of total assets (ROA):

$$
R O A=\frac{\text { netincome }}{\text { total assests }}
$$

2) Size:

Natural logarithm of total assets:

$$
\text { Size }=\ln (\text { total assests })
$$

3) Growth:

Growth rate of sales (or revenues), calculated as per the following equation:

$$
\text { Growth }=\frac{\text { revenue }_{n}-\text { revenue }_{n-1}}{\text { revenue }_{n-1}}
$$

4) Risk:

Defined as the Standard deviation of return on equity ROE, calculated as per the following equation:

$$
R i s k=\sqrt{\frac{R O E_{n}-R O E_{n-1}}{R O E_{n-1}}}
$$

Since the objective of this study is to look for the factors that have influence on capital 
structure, using the variables explained previously, hypotheses of the research are the following:

1) The profitability hypotheses

H0: There is no statistical significant impact of profitability (Profit) on book leverage (booklev).

H1: There is statistical significant impact of profitability (Profit) on book leverage (booklev).

H0: There is no statistical significant impact of profitability (Profit) on market leverage (Marketlev).

H1: There is statistical significant impact of profitability (Profit) on market leverage (Marketlev).

2) The size hypotheses

H0: There is no statistical significant impact of size (size) on book leverage (booklev).

H1: There is statistical significant impact of size (size) on book leverage (booklev).

H0: There is no statistical significant impact of size (size) on market leverage (Marketlev).

H1: There is statistical significant impact of size (size) on market leverage (Marketlev).

3) The growth hypotheses

H0: There is no statistical significant impact of growth (growth) on book leverage (booklev).

H1: There is statistical significant impact of growth (growth) on book leverage (booklev).

H0: There is no statistical significant impact of growth (growth) on market leverage (Marketlev).

H1: There is statistical significant impact of growth (growth) on market leverage (marketlev).

4) The risk hypotheses

H0: There is no statistical significant impact of risk (risk) on book leverage (booklev).

H1: There is statistical significant impact of risk (risk) on book leverage (booklev).

H0: There is no statistical significant impact of risk (risk) on market leverage (marketlev).

H1: There is statistical significant impact of risk (risk) on market leverage (marketlev).

5) Multiple variables hypotheses

H0: There is no statistical significant impact for dependent variables profitability, size, risk and growth on book leverage (booklev).

H1: There is statistical significant impact for dependent variables profitability, size, risk and growth on book leverage (booklev). 
H0: There is no statistical significant impact for dependent variables profitability, size, risk and growth on market leverage (marketlev).

H1: There is statistical significant impact for dependent variables profitability, size, risk and growth on market leverage (marketlev).

\section{Sample of the Study}

The study population consists of all listed companies in Stock Exchange Market-Bahrain Bourse (45 companies). The sample of the study composed of 39 companies covers all the sectors in Bahrain Bourse (Banking, Hotels \& Tourism, Industrial, Insurance, Investment and Services. 5 companies were dropped from the sample because they don't have sufficient data as other companies.

Table 1. The sample of the study

\begin{tabular}{|c|c|c|c|}
\hline & Company & Code & sector \\
\hline 1 & National Bank of Bahrain & NBB & Banking \\
\hline 2 & Bank of Bahrain \& Kuwait & BBK & Banking \\
\hline 3 & Ahli United Bank & AUB & Banking \\
\hline 4 & Bahrain Islamic Bank & BISB & Banking \\
\hline 5 & Al Salam Bank & SALAM & Banking \\
\hline 6 & Ithmaar Bank & ITHMR & Banking \\
\hline 7 & Khaleeji Commercial Bank & KHCB & Banking \\
\hline 8 & Bank Muscat & BMUSC & Banking \\
\hline 9 & National Hotels Co. & NHOTEL & Hotels \& Tourism \\
\hline 10 & Gulf Hotel Group & BHOTEL & Hotels \& Tourism \\
\hline 11 & Bahrain Family Leisure Co. & FAMILY & Hotels \& Tourism \\
\hline 12 & Bahrain Tourism Co. & BTC & Hotels \& Tourism \\
\hline 13 & Banader Hotel Co. & BANADER & Hotels \& Tourism \\
\hline 14 & Aluminum Bahrain B.S.C & ALBH & Industrial \\
\hline 15 & Bahrain Flour Mills Co. & BFM & Industrial \\
\hline 16 & Delmon Poultry Co. & POLTRY & Industrial \\
\hline 17 & Al Ahlia Insurance Co. & AHLIA & Insurance \\
\hline 18 & Arab Insurance Group & ARIG & Insurance \\
\hline 19 & Bahrain Kuwait Insurance Co. & BKIC & Insurance \\
\hline 20 & Bahrain National Holding Co. & $\mathrm{BNH}$ & Insurance \\
\hline 21 & Takaful International Co. & TAKAFUL & Insurance \\
\hline 22 & Arab Banking Corporation & $\mathrm{ABC}$ & Investment \\
\hline 23 & Al Baraka Banking Group & BARKA & Investment \\
\hline 24 & Bahrain Commercial Facilities Co. & $\mathrm{BCFC}$ & Investment \\
\hline 25 & Bahrain Middle East Bank & BMB & Investment \\
\hline 26 & Esterad Investment Co. & ESTERAD & Investment \\
\hline 27 & GFH Financial Group & GFH & Investment \\
\hline 28 & INOVEST & INOVEST & Investment \\
\hline 29 & United Gulf Bank & UGB & Investment \\
\hline 30 & United Gulf Investment Corporation & UGIC & Investment \\
\hline 31 & Bahrain Ship Repairing \& Engineering Co. & BASREC & Services \\
\hline 32 & Bahrain Telecommunication Co. & BATELCO & Services \\
\hline 33 & BMMI B.S.C & BMMI & Services \\
\hline 34 & Bahrain Cinema Co. & CINEMA & Services \\
\hline
\end{tabular}




\begin{tabular}{|l|l|l|l|}
\hline 35 & Bahrain Car Park Co. & CPARK & Services \\
\hline 36 & Bahrain Duty Free Shop Complex Co. & DUTYF & Services \\
\hline 37 & Nass Corporation & NASS & Services \\
\hline 38 & Seef Properties B.S.C. & SEEF & Services \\
\hline 39 & Trafco Group & TRAFCO & Services \\
\hline
\end{tabular}

\section{Data and Methodology}

The goal of this research is to investigate the strength and the direction of the relationship (positive or negative linear relationship) between the dependent variables (leverage ratios) and the independent or explanatory variables (profitability, growth, size and risk). This relationship will be tested in two levels: global level or market level (Bahrain Bourse-Stock Market) which covers in one analysis all the companies of the sample together and sectorial level which covers the analysis of each sector of the sectors in Bahrain Bourse stock market. Data from 2011 to 2015 has been used to test the hypotheses of the research. Balance sheets and income statements of the sample have been analyzed by using Microsoft Excel 2010. SPSS 16.0 (Statistical Package for the Social Sciences) has been used to test the statistical relationship between the variables of the research

The rest of this paper is presented as follows: the research models are explained in the paragraph (6). The empirical analysis (paragraph 7) of the determinant factors of capital structure for listed companies in Bahrain Bourse listed are presented and the same relationship is tested in for each sector of Bahrain Bourse stock market.

\section{Research Models}

Research Model is based on the verification of the existence of linear relationship between dependent and independent variables. In the linear regression model, the dependent variable is assumed to be a linear function of one or more independent variables plus an error considering all other factors. This regression is presented by the function below:

$$
Y=\beta 0+\beta 1 X_{i}+\varepsilon
$$

Where: $\mathrm{Y}$ is the dependent variable, $\mathrm{X}_{\mathrm{i}}$ is the independent or explanatory variable(s), and $\varepsilon$ is the disturbance or error term.

Regression analysis result defines the unknown parameters Beta $(\beta 1$ : The slope of the regression line) which indicates how a change in one unit of the independent variables affects the values taken by the dependent variable. B0 is the intercept point of the regression line and the $\mathrm{Y}$ axis. The strength of relationship between dependent and independent variables is measured by Correlation Coefficient ${ }^{\circledR}$. The percentage of the total variation in the dependent variable by variation in the independent variable is explained by R-square. Accordingly, research models to be tested in this study are the following:

6.1 Profitability and Capital Structure Model

$$
\text { booklev }=\beta 0+\beta 1 \text { Profit }+\varepsilon
$$




$$
\begin{gathered}
\text { and } \\
\text { marketlev }=\beta 0+\beta 1 \text { Profit }+\varepsilon
\end{gathered}
$$

6.2 Size and Capital Structure Model

$$
\begin{gathered}
\text { booklev }=\beta 0+\beta 1 \text { size }+\varepsilon \\
\text { and } \\
\text { marketlev }=\beta 0+\beta 1 \text { size }+\varepsilon
\end{gathered}
$$

6.3 Growth and Capital Structure Model

$$
\begin{gathered}
\text { booklev }=\beta 0+\beta 1 \text { growth }+\varepsilon \\
\text { and } \\
\text { marketlev }=\beta 0+\beta 1 \text { growth }+\varepsilon
\end{gathered}
$$

6.4 Risk and Capital Structure Model

$$
\begin{gathered}
\text { booklev }=\beta 0+\beta 1 \text { risk }+\varepsilon \\
\text { and } \\
\text { Marketlev }=\beta 0+\beta 1 \text { risk }+\varepsilon
\end{gathered}
$$

6.5 The Multiple Regression Model

$$
\begin{gathered}
\text { booklev }=\beta 0+\beta 1 \text { Profit }+\beta 2 \text { size }+\beta 3 \text { growth }+\beta 4 \text { risk }+\varepsilon \\
\text { and } \\
\text { Marketlev }=\beta 0+\beta 1 \text { Profit }+\beta 2 \text { size }+\beta 3 \text { growth }+\beta 4 \text { risk }+\varepsilon
\end{gathered}
$$

\section{Empirical Analysis}

This section is organized as follows: (7.1) descriptive statistical analysis of the variables, (7.2) is exploration of the correlation analysis to identify the significance of the relationship between dependent and independent variables. In (7.3) regression models are tested to deduce the linear relationship between the determinants of capital structure and leverages in Bahrain Bourse (Stock Market) listed companies.

\subsection{Descriptive Analysis}

This descriptive analysis is done at global level (7.1.1. Bahrain Bourse Stock Market) and sectorial level (7.1.2. descriptive analysis by sector)

\subsubsection{Bahrain Bourse Stock Market Descriptive Analysis}

Table 2 shows descriptive statistics for both the dependent variables and the explanatory variables (independent) of 195 observations. The average leverage ratios for the sample are 
(47.82\% book leverage; $31.84 \%$ market leverage). This result is similar to what Rajan \& Zingales (1995) find in United States where they note that book leverage is $52 \%$, and market value leverage is $44 \%$. The profitability ratio shows an average of return on assets (ROA) $3.55 \%$. The average of growth of sales ratio is $5.90 \%$. These results accompanied by an average of business risk about $4.4 \%$.

Table 2. Sample of the research descriptive statistics (Market level)

\begin{tabular}{|l|l|l|l|}
\hline & $\mathrm{N}$ & Mean & Std. Deviation \\
\hline Booklev & 195 & .478227 & .3122301 \\
\hline Marketlev & 195 & .504171 & .3184275 \\
\hline Profit & 195 & .035541 & .0577288 \\
\hline Size & 195 & 12.180339 & 2.0562003 \\
\hline Risk & 195 & .044541 & .0555777 \\
\hline Growth & 195 & .058938 & .5224186 \\
\hline Valid N (listwise) & 195 & & \\
\hline
\end{tabular}

\subsubsection{Sectorial Descriptive Analysis}

Table 3 shows a detailed descriptive analysis for dependent and independent variables of the study.

Table 3. Sectors in Bahrain bourse stock market descriptive statistics

\begin{tabular}{|c|c|c|c|c|c|c|c|c|}
\hline & $\mathrm{N}$ & & Booklev & Marketlev & Profit & Size & Risk & Growth \\
\hline \multirow{2}{*}{$\begin{array}{l}\text { Bahrain } \\
\text { Bourse Stock } \\
\text { Market }\end{array}$} & \multirow[t]{2}{*}{195} & Mean & 0.478227 & 0.504171 & 0.035541 & 12.180339 & 0.044541 & 0.058938 \\
\hline & & Std. Deviation & 0.312230 & 0.318428 & 0.057729 & 2.056200 & 0.055578 & 0.522419 \\
\hline \multirow[t]{2}{*}{ Hotel Sector } & \multirow[t]{2}{*}{25} & Mean & 0.145213 & 0.198614 & 0.053597 & 10.397843 & 0.040405 & 0.008621 \\
\hline & & Std. Deviation & 0.115029 & 0.168632 & 0.083219 & 0.985495 & 0.056872 & 0.426357 \\
\hline \multirow{2}{*}{$\begin{array}{l}\text { Insurance } \\
\text { sector }\end{array}$} & \multirow[t]{2}{*}{25} & Mean & 0.626188 & 0.6 & 61 & $11.26^{\prime}$ & 0.064312 & 0.020999 \\
\hline & & Std. Deviation & 0.139780 & 0.182052 & 0.032046 & 0.968294 & 0.056330 & 0.111960 \\
\hline \multirow{2}{*}{$\begin{array}{l}\text { Industrial } \\
\text { Sector }\end{array}$} & \multirow[t]{2}{*}{15} & Mean & 0.176307 & 0.244582 & 0.058024 & 11.226903 & 0.033072 & -0.015775 \\
\hline & & Std. Deviation & 0.106184 & 0.119489 & 0.036749 & 2.039127 & 0.026094 & 0.068670 \\
\hline \multirow{2}{*}{$\begin{array}{l}\text { Banking } \\
\text { Sector }\end{array}$} & \multirow[t]{2}{*}{40} & Mean & 0.865671 & 0.870173 & 0.006958 & 14.733049 & 0.052717 & 0.087541 \\
\hline & & Std. Deviation & 0.048004 & 0.047514 & 0.014303 & 1.025908 & 0.076865 & 0.171923 \\
\hline \multirow{2}{*}{$\begin{array}{l}\text { Service } \\
\text { Sector }\end{array}$} & \multirow[t]{2}{*}{45} & Mean & 0.208197 & 0.209347 & 0.084219 & 11.081926 & 0.017047 & 0.026978 \\
\hline & & Std. Deviation & 0.157272 & 0.201640 & 0.042131 & 1.148823 & 0.009399 & 0.138297 \\
\hline \multirow{2}{*}{$\begin{array}{l}\text { Investment } \\
\text { Sector }\end{array}$} & \multirow[t]{2}{*}{45} & Mean & 0.607308 & 0.674559 & 0.003291 & 12.824655 & 0.059904 & 0.139409 \\
\hline & & Std. Deviation & 0.216765 & 0.210326 & 0.056995 & 1.963156 & 0.056836 & 1.018798 \\
\hline
\end{tabular}


Descriptive table (table 3 ) shows that the best average profitability is in service sector $(8.4 \%)$ with standard deviation of (0.04). It shows either that investment sector and banking sector recorded the poorest performance all over the period of the study $(0.03 \%$ and $0.06 \%)$ respectively. Results show also minimum financial risk level in service sector $(0.017)$ with a standard deviation of (0.009). Insurance and Investment sectors are the riskiest with an average of (0.064) and (0.0599). The economic recession and regional conflicts affects directly the profitability and the stability of the revenues in investment and banking sectors. On the other hand, there is almost a good stable domestic and touristic demand for the services sector in Bahrain as it classified as an attractive touristic country for the people from the Gulf countries.

\subsection{Correlation Analysis}

Correlation between dependent and independent variables is studied market level and sectors level.

\subsubsection{Bahrain Bourse Stock Market Correlation Analysis}

The results of the Pearson's correlation of the models are shown in the table 4, and described as follows:

A negative significant correlation is observed between profitability, and leverage ratios (market and book leverage). A positive significant correlation is detected between size of the firm, and leverage ratios (market and book leverage). Another positive significant correlation is observed between market leverage and firm risk. A positive non-significant correlation is seen in the relationship between book leverage and firm risk. A positive non-significant correlation also is observed between leverage ratios and firm growth.

Table 4. Bahrain bourse stock market correlation analysis

\begin{tabular}{|l|l|l|l|l|l|}
\hline \multicolumn{2}{|c|}{} & Profit & Size & Risk & Growth \\
\hline \multirow{4}{*}{ Booklev } & Pearson Correlation & $-.471^{* *}$ & $.763^{* *}$ & .135 & .091 \\
\cline { 2 - 6 } & Sig. (2-tailed) & .000 & .000 & .061 & .208 \\
\cline { 2 - 6 } & $\mathrm{N}$ & 195 & 195 & 195 & 195 \\
\hline \multirow{3}{*}{ Marketlev } & Pearson Correlation & $-.563^{* *}$ & $.751^{* *}$ & $.141^{*}$ & .077 \\
\cline { 2 - 6 } & Sig. (2-tailed) & .000 & .000 & .049 & .283 \\
\cline { 2 - 6 } & $\mathrm{N}$ & 195 & 195 & 195 & 195 \\
\hline
\end{tabular}

Note. **. Correlation is significant at the 0.01 level (2-tailed). *. Correlation is significant at the 0.05 level (2-tailed).

\subsubsection{Bahrain Bourse Stock Market Sectors Correlations Analysis}

Correlation analysis sectorial level is done all over the six sectors chosen for this study. 


\subsubsection{Correlation Analysis in Hotel Sector}

Pearson's correlation results presented in table 5 show the following remarks:

In hotel sector, only one significant correlation is observed. It is a negative significant correlation between profitability and market leverage. All other correlations between dependent and independent variables are not significant positively or negatively.

Table 5. Hotel sector correlations

\begin{tabular}{|l|l|l|l|l|l|}
\hline \multicolumn{2}{|c|}{} & Profit & Size & Risk & Growth \\
\hline \multirow{4}{*}{ Booklev } & Pearson Correlation & -.339 & .195 & -.268 & -.311 \\
\cline { 2 - 6 } & Sig. (2-tailed) & .097 & .351 & .196 & .130 \\
\cline { 2 - 6 } & $\mathrm{N}$ & 25 & 25 & 25 & 25 \\
\hline \multirow{3}{*}{ Marketlev } & Pearson Correlation & $-.465^{*}$ & .181 & -.297 & -.378 \\
\cline { 2 - 6 } & Sig. (2-tailed) & .019 & .388 & .150 & .062 \\
\cline { 2 - 6 } & $\mathrm{N}$ & 25 & 25 & 25 & 25 \\
\hline
\end{tabular}

Note. **. Correlation is significant at the 0.01 level (2-tailed). *. Correlation is significant at the 0.05 level (2-tailed).

\subsubsection{Correlation Analysis in Insurance Sector}

The results of the Pearson's correlation of the model in insurance sector are presented in the table 6, and described as follows:

A negative significant correlation is observed between profitability, and leverage ratios (market and book leverage). A positive significant correlation is detected between size of the firm and market leverage. A positive significant correlation is seen in the relationship between book leverage and firm risk. Another positive non-significant correlation is observed between market leverage and firm risk. A negative non-significant correlation is found between growth and leverages (book and market leverage).

Table 6. Insurance sector correlations

\begin{tabular}{|l|l|l|l|l|l|}
\hline \multicolumn{2}{|c|}{} & Profit & Size & Risk & Growth \\
\hline \multirow{5}{*}{ Booklev } & Pearson Correlation & $-.611^{* *}$ & .239 & $.626^{* *}$ & -.062 \\
\cline { 2 - 6 } & Sig. (1-tailed) & .001 & .125 & .000 & .383 \\
\cline { 2 - 6 } & $\mathrm{N}$ & 25 & 25 & 25 & 25 \\
\hline \multirow{5}{*}{ Marketlev } & Pearson Correlation & $-.543^{* *}$ & $.690^{* *}$ & .242 & -.088 \\
\cline { 2 - 6 } & Sig. (1-tailed) & .003 & .000 & .122 & .338 \\
\cline { 2 - 6 } & $\mathrm{N}$ & 25 & 25 & 25 & 25 \\
\hline
\end{tabular}

Note. ${ }^{* *}$. Correlation is significant at the 0.01 level (2-tailed). *. Correlation is significant at the 0.05 level (2-tailed). 


\subsubsection{Correlation Analysis in Industrial Sector}

In Industrial sector table 5 shows a positive significant correlation between book leverage and two independent variables: size and risk. All other correlations are not significant.

Table 7. Industrial sector correlations

\begin{tabular}{|l|l|l|l|l|l|}
\hline \multicolumn{2}{|c|}{} & Profit & Size & Risk & Growth \\
\hline \multirow{3}{*}{ Booklev } & Pearson Correlation & .384 & $.721^{* *}$ & $.645^{* *}$ & -.367 \\
\cline { 2 - 6 } & Sig. (2-tailed) & .157 & .002 & .009 & .178 \\
\cline { 2 - 6 } & $\mathrm{N}$ & 15 & 15 & 15 & 15 \\
\hline \multirow{3}{*}{ Marketlev } & Pearson Correlation & .008 & .508 & .371 & -.320 \\
\cline { 2 - 6 } & Sig. (2-tailed) & .977 & .053 & .173 & .245 \\
\cline { 2 - 6 } & $\mathrm{N}$ & 15 & 15 & 15 & 15 \\
\hline
\end{tabular}

Note. **. Correlation is significant at the 0.01 level (2-tailed). *. Correlation is significant at the 0.05 level (2-tailed).

\subsubsection{Correlation Analysis in Banking Sector}

The results of the Pearson's correlation of the model in banking sector are presented in table 8 which shows a significant negative correlation between profitability and market leverage. A positive significant correlation is detected between size of the firm and book leverage. All other correlations are not significant.

Table 8. Banking sector correlations

\begin{tabular}{|l|l|l|l|l|l|}
\hline \multicolumn{2}{|c|}{} & Profit & Size & Risk & Growth \\
\hline \multirow{5}{*}{ Booklev } & Pearson Correlation & .042 & $.505^{* *}$ & .099 & -.198 \\
\cline { 2 - 6 } & Sig. (2-tailed) & .799 & .001 & .542 & .220 \\
\cline { 2 - 6 } & $\mathrm{N}$ & 40 & 40 & 40 & 40 \\
\hline \multirow{3}{*}{ Marketlev } & Pearson Correlation & $-.544^{* *}$ & -.143 & .183 & .078 \\
\cline { 2 - 6 } & Sig. (2-tailed) & .000 & .380 & .258 & .634 \\
\cline { 2 - 6 } & $\mathrm{N}$ & 40 & 40 & 40 & 40 \\
\hline
\end{tabular}

Note. **. Correlation is significant at the 0.01 level (2-tailed). *. Correlation is significant at the 0.05 level (2-tailed).

\subsubsection{Correlation Analysis in Service Sector}

The results of the Pearson's correlation of the model in service sector are presented in the table 9, and described as follows:

A negative significant correlation is observed between profitability, and leverage ratios 
(market and book leverage). A positive significant correlation is detected between size of the firm and leverage ratios (market and book leverage). Another negative significant correlation is observed between market leverage and firm risk. A positive non-significant correlation is seen in the relationship between firm growth and leverage ratios (market and book leverage).

Table 9. Service sector Correlations

\begin{tabular}{|l|l|l|l|l|l|}
\hline \multicolumn{2}{|c|}{} & Profit & Size & Risk & Growth \\
\hline \multirow{4}{*}{ Booklev } & Pearson Correlation & $-.374^{*}$ & $.473^{* *}$ & -.177 & .126 \\
\cline { 2 - 6 } & Sig. (2-tailed) & .011 & .001 & .244 & .411 \\
\cline { 2 - 6 } & $\mathrm{N}$ & 45 & 45 & 45 & 45 \\
\hline \multirow{4}{*}{ Marketlev } & Pearson Correlation & $-.550^{* *}$ & $.444^{* *}$ & $-.295^{*}$ & .141 \\
\cline { 2 - 6 } & Sig. (2-tailed) & .000 & .002 & .049 & .355 \\
\cline { 2 - 6 } & $\mathrm{N}$ & 45 & 45 & 45 & 45 \\
\hline
\end{tabular}

Note. **. Correlation is significant at the 0.01 level (2-tailed). *. Correlation is significant at the 0.05 level (2-tailed).

\subsubsection{Correlation Analysis in Investment Sector}

In investment sector, the result of Pearson's correlation is presented in the table 10 which shows that there is a negative significant correlation between risk and leverage ratios (market and book leverage). A positive significant correlation is detected between size of the firm and leverage ratios (market and book leverage). A positive non-significant correlation is seen in the relationship between firm growth and leverage ratios (market and book leverage) and between profitability and leverage ratios.

Table 10. Investment sector correlations

\begin{tabular}{|l|l|l|l|l|l|}
\hline \multicolumn{2}{|c|}{} & Profit & Size & Risk & Growth \\
\hline \multirow{4}{*}{ Booklev } & Pearson Correlation & .210 & $.769^{* *}$ & $-.665^{* *}$ & .136 \\
\cline { 2 - 6 } & Sig. (2-tailed) & .166 & .000 & .000 & .373 \\
\cline { 2 - 6 } & $\mathrm{N}$ & 45 & 45 & 45 & 45 \\
\hline \multirow{3}{*}{ Marketlev } & Pearson Correlation & .041 & $.758^{* *}$ & $-.480^{* *}$ & .105 \\
\cline { 2 - 6 } & Sig. (2-tailed) & .790 & .000 & .001 & .494 \\
\cline { 2 - 6 } & $\mathrm{N}$ & 45 & 45 & 45 & 45 \\
\hline
\end{tabular}

Note. **. Correlation is significant at the 0.01 level (2-tailed). *. Correlation is significant at the 0.05 level (2-tailed).

\subsubsection{Correlation Analysis Summary}

All the results of correlation analysis can be resumed in the following table: 
Table 11. Resume of correlation analysis — sectors and stock market Bahrain Bourse

\begin{tabular}{|c|c|c|c|c|c|}
\hline Dependent & Sector & Profit & Size & Risk & Growth \\
\hline \multirow{7}{*}{ Booklev } & Banking & N/A & $\mathrm{S}+$ & N/A & N/A \\
\hline & Hotels \& Tourism & N/A & $\mathrm{N} / \mathrm{A}$ & $\mathrm{N} / \mathrm{A}$ & $\mathrm{N} / \mathrm{A}$ \\
\hline & Industrial & $\mathrm{N} / \mathrm{A}$ & $\mathrm{S}+$ & $\mathrm{S}+$ & N/A \\
\hline & Insurance & S- & $\mathrm{N} / \mathrm{A}$ & $\mathrm{S}+$ & N/A \\
\hline & Investment & $\mathrm{N} / \mathrm{A}$ & $\mathrm{S}+$ & S- & N/A \\
\hline & Services & S- & $\mathrm{S}+$ & N/A & N/A \\
\hline & Stock Market & S- & $\mathrm{S}+$ & N/A & N/A \\
\hline \multirow{7}{*}{ Marketlev } & Banking & S- & N/A & N/A & N/A \\
\hline & Hotels \& Tourism & S- & $\mathrm{N} / \mathrm{A}$ & N/A & N/A \\
\hline & Industrial & $\mathrm{N} / \mathrm{A}$ & N/A & N/A & N/A \\
\hline & Insurance & S - & $\mathrm{S}+$ & $\mathrm{N} / \mathrm{A}$ & $\mathrm{N} / \mathrm{A}$ \\
\hline & Investment & $\mathrm{N} / \mathrm{A}$ & $\mathrm{S}+$ & S- & N/A \\
\hline & Services & $\mathrm{S}-$ & $\mathrm{S}+$ & S - & N/A \\
\hline & Stock Market & S - & $\mathrm{S}+$ & $\mathrm{S}+$ & N/A \\
\hline \multicolumn{6}{|c|}{ S- : A negative significant correlation } \\
\hline \multicolumn{6}{|c|}{$\mathrm{S}+$ : A positive significant correlation } \\
\hline \multicolumn{6}{|c|}{ N/A: Non-significant correlation } \\
\hline
\end{tabular}

It is clear from the table above that there is no significant relationship between growth and leverages in all sectors and market level. For the independent variables: profitability and size, the relationship is significant and it has the same direction (positive, negative respectively) in market level. The risk has significance relationship with market leverage in sectors and market level while this relationship isn't significant at market level with the book leverage.

\subsection{Regression Analysis and Hypotheses Test}

Regression analysis is carried out in order to test the impact of each independent variable on the dependent variables, and the impact of multiple independent variables on dependent variables. This analysis has been done on market level only. The results of regression analysis are shown in the following discussions.

\subsubsection{Profitability Regression Model and Hypotheses Test:}

a) Book leverage-Profitability Regression

As it has been previously presented, the regression models profitability capital structure are expressed in the following equations (2) and (3):

$$
\begin{gathered}
\text { booklev }=\beta 0+\beta 1 \text { Profit }+\varepsilon \\
\text { and } \\
\text { marketlev }=\beta 0+\beta 1 \text { Profit }+\varepsilon
\end{gathered}
$$




\section{Macrothink}

Result of regression analysis related to equation (2) is given in table 12, which demonstrates that profitability is negatively related to book leverage with correlation coefficient (R) of $(\mathrm{R}=47.10 \%)$. The coefficient of determination $\mathrm{R}$ square equals $22.2 \%$ which represents the variation in book leverage explained by variation in the profitability.

Table 12. Book leverage - profitability regression model summary

\begin{tabular}{|l|l|l|l|l|}
\hline Model & $\mathrm{R}$ & $\mathrm{R}$ Square & Adjusted R Square & Std. Error of the Estimate \\
\hline 1 & $.471^{\mathrm{a}}$ & .222 & .218 & .2761292 \\
\hline
\end{tabular}

The coefficient of the equation is given either in table 13 which shows that:

$\beta 0=0.569$

$\beta 1=-2.548$

Table 13. Book value - profitability regression model Coefficients ${ }^{\mathrm{a}}$

\begin{tabular}{|l|l|l|l|l|l|l|}
\hline \multicolumn{2}{|l|}{ Model } & \multicolumn{2}{|l|}{ Unstandardized Coefficients } & Standardized Coefficients & t & Sig. \\
\cline { 3 - 7 } \multicolumn{2}{|l|}{} & B & Std. Error & Beta & & \\
\hline \multirow{2}{*}{1} & (Constant) & .569 & .023 & & 24.477 & .000 \\
\cline { 2 - 7 } & Profit & -2.548 & .343 & -.471 & -7.419 & .000 \\
\hline \multicolumn{2}{|l|}{ a. Dependent Variable: Booklev } \\
\hline
\end{tabular}

The profitability regression model will be:

$$
\text { booklev }=0.569-2.548 \text { Profit }
$$

It is clear from the model that a change of one unit in profit will lead to a change book leverage by 2.548 in the opposite direction, which reflects strong and negative effect of profitability on book leverage. This relationship is significant at a level of $\mathbf{5 \%}$ because sig $\underline{=0 .}$

This result leads to reject $\mathrm{H} 0$ profitability book leverage hypothesis (there is no statistical significant impact of profitability on book leverage) and accept $\mathrm{H} 1$ book leverage profitability hypothesis (There is statistical significant impact of profitability on book leverage).

b) Market leverage_-Profitability Regression

Regarding the market value regression model, table 14 represents the summary analysis 
Table 14. Market value- profitability regression model summary

\begin{tabular}{|l|l|l|l|l|}
\hline Model & $\mathrm{R}$ & R Square & Adjusted R Square & Std. Error of the Estimate \\
\hline 1 & $.563^{\mathrm{a}}$ & .316 & .313 & .2639386 \\
\hline \multicolumn{3}{|l|}{ a. Predictors: (Constant), Profit } \\
\hline
\end{tabular}

Results of regression analysis demonstrate that profitability is negatively related to market leverage with correlation coefficient $(\mathrm{R})$ of $(\mathrm{R}=56.3 \%)$. The coefficient of determination $\mathrm{R}$ square equals $31.6 \%$ which represents the variation in market leverage explained by variation in the profitability.

Table 15 shows the coefficient of the equation (3) where:

$\beta 0=0.614$

$\beta 1=-3.103$

Table 15. Market leverage-profitability regression model Coefficients ${ }^{\mathrm{a}}$

\begin{tabular}{|l|l|l|l|l|l|l|}
\hline \multicolumn{2}{|l|}{ Model } & \multicolumn{2}{|l|}{ Unstandardized Coefficients } & Standardized Coefficients & \multirow{2}{*}{ Sig. } \\
\cline { 3 - 7 } \multicolumn{2}{|l|}{} & B & Std. Error & Beta & & \\
\hline \multirow{2}{*}{1} & $($ Constant) & .614 & .022 & & 27.664 & .000 \\
\cline { 2 - 7 } & Profit & -3.103 & .328 & -.563 & -9.454 & .000 \\
\hline \multicolumn{2}{|l|}{ a. Dependent Variable: Marketlev } \\
\hline
\end{tabular}

According to the regression analysis results, the profitability regression model will be:

$$
\text { Marketlev }=0.614-3.103 \text { Profit }
$$

The equation shows that a change of one unit in profit will lead to a change in market leverage by 3.103 in the opposite direction which reflects strong and negative effect of profitability on market leverage. This relationship is significant at a level of $5 \%$ because $\underline{\text { sig }=0 .}$

This result leads to reject $\mathrm{H} 0$ profitability market leverage hypothesis (there is no statistical significant impact of profitability on market leverage) and to accept H1 market leverage profitability hypothesis (There is statistical significant impact of profitability on market leverage).

\subsubsection{Size Regression Model and Hypotheses Test}

a) Book leverage-Size Regression

As it has been explained in (4) and (5), the regression models size capital structure are expressed in the following equations: 


$$
\begin{gathered}
\text { booklev }=\beta 0+\beta 1 \text { size }+\varepsilon \\
\text { and } \\
\text { marketlev }=\beta 0+\beta 1 \text { size }+\varepsilon
\end{gathered}
$$

Result of regression analysis related to equation (16) is given in table 16:

Table 16. Book leverage — size regression model summary

\begin{tabular}{|l|l|l|l|l|}
\hline Model & R & R Square & Adjusted R Square & Std. Error of the Estimate \\
\hline 1 & $.763^{\mathrm{a}}$ & .583 & .580 & .2022548 \\
\hline \multicolumn{4}{|l|}{ a. Predictors: (Constant), Size } \\
\hline
\end{tabular}

The Table 16 shows that size is positively related to book leverage with correlation coefficient $(R)$ of $(R=76.3 \%)$. The coefficient of determination $R$ square equals $58.3 \%$ which represents the variation in book leverage explained by variation in the size.

The coefficient of the equation (4) is given either in table 17 which shows that:

$\beta 0=-0.933$

$\beta 1=0.116$

Table 17. Book leverage -size regression model Coefficients ${ }^{\mathrm{a}}$

\begin{tabular}{|l|l|l|l|l|l|l|}
\hline \multicolumn{2}{|l|}{ Model } & \multicolumn{2}{l|}{ Unstandardized Coefficients } & Standardized Coefficients & t & Sig. \\
\cline { 3 - 7 } \multicolumn{2}{|l|}{} & B & Std. Error & Beta & & \\
\hline \multirow{2}{*}{1} & (Constant) & -.933 & .087 & & -10.701 & .000 \\
\cline { 2 - 7 } & Size & .116 & .007 & .763 & 16.411 & .000 \\
\hline \multicolumn{2}{|l|}{ a. Dependent Variable: Booklev }
\end{tabular}

The book value size regression model will be:

$$
\text { booklev }=-0.933+0.116 \text { Size }
$$

It is clear from the model that a change of one unit in size will lead to a change book leverage by 0.116 in the same direction which reflects weak and positive effect of size on book leverage. This relationship is significant at a level of $5 \%$ because sig $=0$.

This result leads to reject $\mathrm{H} 0$ size-book leverage hypothesis (there is no statistical significant impact of size on book leverage) and to accept $\mathrm{H} 1$ size-book leverage hypothesis (There is statistical significant impact of size on book leverage).

b) Market leverage-Size Regression 
Regarding the market value regression model, table 18 represents the summary analysis

Table 18. Market leverage — size regression model summary

\begin{tabular}{|l|l|l|l|l|}
\hline Model & R & R Square & Adjusted R Square & Std. Error of the Estimate \\
\hline 1 & $.751^{\mathrm{a}}$ & .563 & .561 & .2109640 \\
\hline \multicolumn{3}{|l|}{ a. Predictors: (Constant), Size } \\
\hline
\end{tabular}

Result of regression analysis demonstrates that size is negatively related to the market leverage with correlation coefficient $(\mathrm{R})$ of $(\mathrm{R}=75.1 \%)$. The coefficient of determination $\mathrm{R}$ square equals $56.3 \%$ which represents the variation in market leverage explained by variation in the size.

Table 19 shows the coefficient of the equation (5) where:

$\beta 0=-0.912$

$\beta 1=-0.116$

Table 19. Market leverage—-size regression model Coefficients ${ }^{\mathrm{a}}$

\begin{tabular}{|l|l|l|l|l|l|l|}
\hline \multicolumn{2}{|l|}{ Model } & \multicolumn{2}{|l|}{ Unstandardized Coefficients } & Standardized Coefficients & t & Sig. \\
\cline { 3 - 8 } \multicolumn{2}{|l|}{1} & B & Std. Error & Beta & & \\
\hline \multirow{2}{*}{1} & $($ Constant $)$ & -.912 & .091 & & -10.019 & .000 \\
\cline { 2 - 7 } & Size & .116 & .007 & .751 & 15.779 & .000 \\
\hline \multicolumn{2}{|l|}{ a. Dependent Variable: Marketlev } \\
\hline
\end{tabular}

The size regression model will be:

$$
\text { Marketlev }=-0.912+0.116 \text { Size }
$$

The equation shows that a change of one unit in size will lead to a change in market leverage by 0.116 in the opposite direction which reflects weak and negative effect of size on the market leverage. This relationship is significant at a level of $5 \%$ because sig $=0$.

This result leads to reject $\mathrm{HO}$ size-market leverage hypothesis (there is no statistical significant impact of size on market leverage) and to accept H1 size-market leverage hypothesis (There is statistical significant impact of size on market leverage).

7.3.3 Growth Regression Model and hypotheses test:

a) Book leverage - growth Regression

Regression models for growth-leverage are expressed in the following equations: 


$$
\begin{gathered}
\text { booklev }=\beta 0+\beta 1 \text { growth }+\varepsilon \\
\text { and } \\
\text { marketlev }=\beta 0+\beta 1 \text { growth }+\varepsilon
\end{gathered}
$$

Result of regression analysis related to equation (6) is given in table 20:

Table 20. Book value — growth regression model summary

\begin{tabular}{|l|l|l|l|l|}
\hline Model & $\mathrm{R}$ & R Square & Adjusted R Square & Std. Error of the Estimate \\
\hline 1 & $.091^{\mathrm{a}}$ & .008 & .003 & .3117518 \\
\hline
\end{tabular}

Result in the table shows that growth is positively related to book leverage with correlation coefficient $(\mathrm{R})$ of $(\mathrm{R}=9.1 \%)$. The coefficient of determination $\mathrm{R}$ square equals $0.8 \%$ which represents the variation in book leverage explained by variation in the size.

The coefficient of the equation (6) is given either in table 21 which shows that:

$\beta 0=-0.933$

$\beta 1=0.116$

Table 21. Book leverage-growth regression model Coefficients ${ }^{\text {a }}$

\begin{tabular}{|l|l|l|l|l|l|l|}
\hline \multicolumn{2}{|l|}{ Model } & \multicolumn{2}{|l|}{ Unstandardized Coefficients } & Standardized Coefficients & t & Sig. \\
\cline { 3 - 7 } \multicolumn{2}{|l|}{} & B & Std. Error & Beta & & \\
\hline \multirow{2}{*}{1} & $($ Constant $)$ & .475 & .022 & & 21.143 & .000 \\
\cline { 2 - 7 } & Growth & .054 & .043 & .091 & 1.263 & .208 \\
\hline \multicolumn{2}{|l|}{ a. Dependent Variable: Booklev } \\
\hline
\end{tabular}

The book value growth regression model will be:

$$
\text { booklev }=0.475+0.054 \text { Growth }
$$

It is clear from the model that a change of one unit in growth will lead to a change book leverage by 0.054 in the same direction which reflects weak and positive effect of growth on book leverage. This relationship is not significant at a level of $5 \%$ because sig $=\mathbf{0 . 2 0 8}$.

This result leads to accept $\mathrm{H} 0$ growth-book leverage hypothesis (there is no statistical significant impact of growth on book leverage) and to reject H1 growth-book leverage hypothesis (There is statistical significant impact of growth on book leverage).

b) Market leverage - growth Regression 
Regarding the market value regression model, table 22 represents the summary analysis

Table 22. Market leverage - growth regression model summary

\begin{tabular}{|l|l|l|l|l|}
\hline Model & $\mathrm{R}$ & $\mathrm{R}$ Square & Adjusted R Square & Std. Error of the Estimate \\
\hline 1 & $.077^{\mathrm{a}}$ & .006 & .001 & .3182980 \\
\hline
\end{tabular}

Result of regression analysis demonstrates that growth is positively related to the market leverage with correlation coefficient $(\mathrm{R})$ of $(\mathrm{R}=7.7 \%)$. The coefficient of determination $\mathrm{R}$ square equals $0.6 \%$ which represents the variation in market leverage explained by variation in the growth variable.

Table 23 shows the coefficient of the equation (7) where:

$\beta 0=0.501$

$\beta 1=0.047$

Table 23. Market leverage — growth regression model Coefficients ${ }^{\text {a }}$

\begin{tabular}{|l|l|l|l|l|l|l|}
\hline \multicolumn{2}{|l|}{ Model } & \multicolumn{2}{|l|}{ Unstandardized Coefficients } & Standardized Coefficients & t & Sig. \\
\cline { 3 - 8 } \multicolumn{2}{|l|}{} & B & Std. Error & Beta & & \\
\hline \multirow{2}{*}{1} & $($ Constant $)$ & .501 & .023 & & 21.858 & .000 \\
\cline { 2 - 7 } & Growth & .047 & .044 & .077 & 1.076 & .283 \\
\hline \multicolumn{2}{|l|}{ a. Dependent Variable: Marketlev } \\
\hline
\end{tabular}

The size regression model will be:

$$
\text { Marketlev }=0.501+0.047 \text { Growth }
$$

The equation shows that a change of one unit in growth will lead to a change in market leverage by 0.047 in the opposite direction which reflects weak and negative effect of growth on market leverage. This relationship is not significant at a level of $5 \%$ because sig = $\underline{0.283}$.

This result leads to accept $\mathrm{H} 0$ growth-market leverage hypothesis (there is no statistical significant impact of growth on market leverage) and to reject H1 growth-market leverage hypothesis (There is statistical significant impact of growth on market leverage).

7.3.4 Risk Regression Model and Hypotheses Test

c) Book leverage-Risk Regression

Regression models for risk-leverage are expressed in the following equations: 


$$
\begin{gathered}
\text { booklev }=\beta 0+\beta 1 \text { risk }+\varepsilon \\
\text { and } \\
\text { marketlev }=\beta 0+\beta 1 \text { risk }+\varepsilon
\end{gathered}
$$

Result of regression analysis related to equation (8) is given in table 24 :

Table 24. Book leverage_-risk regression model summary

\begin{tabular}{|l|l|l|l|l|}
\hline Model & $\mathrm{R}$ & R Square & Adjusted R Square & Std. Error of the Estimate \\
\hline 1 & $.135^{\mathrm{a}}$ & .018 & .013 & .3101917 \\
\hline
\end{tabular}

Result in the table shows that Risk is positively related to book leverage with correlation coefficient $(\mathrm{R})$ of $(\mathrm{R}=13.5 \%)$. The coefficient of determination $\mathrm{R}$ square equals $1.8 \%$ which represents the variation in book leverage explained by variation in the risk.

The coefficient of the equation (8) is given either in table 25 which shows that:

$\beta 0=0.445$

$\beta 1=0.756$

Table 25. Book leverage-risk regression model Coefficients ${ }^{\text {a }}$

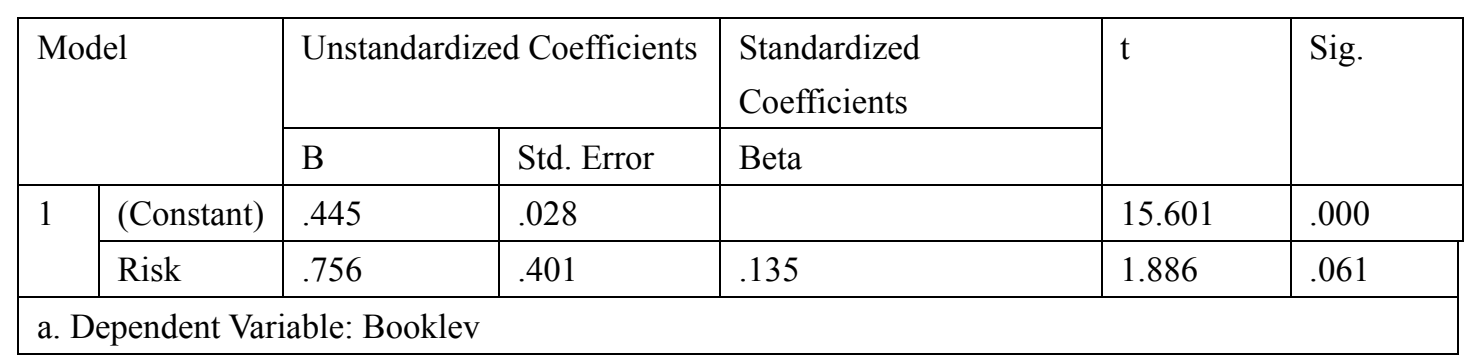

The book value risk regression model will be:

$$
\text { booklev }=0.445+0.756 \text { Risk }
$$

It is clear from the model that a change of one unit in risk will lead to a change book leverage by 0.756 in the same direction which reflects weak and positive effect of risk on book leverage. This relationship is not significant at a level of $5 \%$ because sig $=0.061$.

This result leads to accept $\mathrm{H} 0$ risk-book leverage hypothesis (there is no statistical significant impact of risk on book leverage) and to reject $\mathrm{H} 1$ risk-book leverage hypothesis (There is statistical significant impact of risk on book leverage). 
d) Market leverage -risk Regression

Regarding the market value regression model, table 26 represents the summary analysis

Table 26. Market leverage_-risk regression model summary

\begin{tabular}{|l|l|l|l|l|}
\hline Model & $\mathrm{R}$ & R Square & Adjusted R Square & Std. Error of the Estimate \\
\hline 1 & $.141^{\mathrm{a}}$ & .020 & .015 & .3160617 \\
\hline
\end{tabular}

Result of regression analysis demonstrates that risk is positively related to the market leverage with correlation coefficient $(\mathrm{R})$ of $(\mathrm{R}=14.1 \%)$. The coefficient of determination $\mathrm{R}$ square equals $2.0 \%$ which represents the variation in market leverage explained by variation in the risk variable.

Table 27 shows the coefficient of the equation (9) where:

$\beta 0=0.468$

$\beta 1=0.808$

Table 27. Market leverage_-risk regression model Coefficients ${ }^{\text {a }}$

\begin{tabular}{|l|l|l|l|l|l|l|}
\hline \multicolumn{2}{|l|}{ Model } & \multicolumn{2}{l|}{ Unstandardized Coefficients } & Standardized Coefficients & t & \multirow{2}{*}{ Sig. } \\
\cline { 3 - 5 } \multicolumn{2}{|l|}{} & B & Std. Error & Beta & & \\
\hline \multirow{2}{*}{1} & (Constant) & .468 & .029 & & 16.125 & .000 \\
\cline { 2 - 7 } & Risk & .808 & .408 & .141 & 1.979 & .049 \\
\hline \multicolumn{2}{|l|}{ a. Dependent Variable: Marketlev }
\end{tabular}

The risk regression model will be:

$$
\text { Marketlev }=0.468+0.808 \text { Risk }
$$

The equation shows that a change of one unit in risk will lead to a change in market leverage by 0.808 in the same direction which reflects weak and positive effect of risk on market leverage. This relationship is not significant at a level of $5 \%$ because sig $=\mathbf{0 . 0 6 1}$.

This result leads to accept $\mathrm{H} 0$ risk-market leverage hypothesis (there is no statistical significant impact of risk on market leverage) and to reject H1 risk-market leverage hypothesis (There is statistical significant impact of risk on market leverage).

7.3.5 Multiple Regression Model and Hypotheses Test

The Book leverage Multiple Regression model is: 


$$
\text { booklev }=\beta 0+\beta 1 \text { Profit }+\beta 2 \text { size }+\beta 3 \text { growth }+\beta 4 \text { risk }+\varepsilon
$$

The Book leverage Multiple Regression model is:

$$
\text { Marketlev }=\beta 0+\beta 1 \text { Profit }+\beta 2 \text { size }+\beta 3 \text { growth }+\beta 4 \text { risk }+\varepsilon
$$

a) Book leverage - Multiple Regression Model

Result of regression analysis related to equation (10) is given in table 28:

Table 28. Book value-multi regression model summary

\begin{tabular}{|l|l|l|l|l|}
\hline Model & $\mathrm{R}$ & $\mathrm{R}$ Square & Adjusted R Square & Std. Error of the Estimate \\
\hline 1 & $.842^{\mathrm{a}}$ & .708 & .702 & .1703725 \\
\hline
\end{tabular}

Result in the table shows that dependent variables are related to book leverage with correlation coefficient $(\mathrm{R})$ of $(\mathrm{R}=84.2 \%)$. The coefficient of determination $\mathrm{R}$ square equals $70.8 \%$ which represents the variation in book leverage explained by the variation of independent variables.

The coefficient of the equation (10) is given either in table 29 which shows that:

$\beta 0=-.897$

$\beta 1=-1.286$

$\beta 2=0.112$

$\beta 3=0.028$

$\beta 4=1.152$

\begin{tabular}{|c|c|c|c|c|c|c|}
\hline \multirow{2}{*}{\multicolumn{2}{|c|}{ Model }} & \multicolumn{2}{|c|}{ Unstandardized Coefficients } & \multirow{2}{*}{$\begin{array}{l}\text { Standardized Coefficients } \\
\text { Beta }\end{array}$} & \multirow[t]{2}{*}{$\mathrm{t}$} & \multirow[t]{2}{*}{ Sig. } \\
\hline & & $\mathrm{B}$ & Std. Error & & & \\
\hline \multirow[t]{5}{*}{1} & (Constant) & -.897 & .086 & & -10.392 & .000 \\
\hline & Profit & -1.286 & .237 & -.238 & -5.438 & .000 \\
\hline & Size & .112 & .006 & .740 & 17.406 & .000 \\
\hline & Growth & .028 & .024 & .047 & 1.172 & .243 \\
\hline & Risk & 1.152 & .240 & .205 & 4.795 & .000 \\
\hline
\end{tabular}

Table 29. Book value-multi regression Coefficients ${ }^{\text {a }}$

The book value multi regression model will be: 
booklev $=-0.897-1.268$ Profit +0.112 size +0.028 growth +1.152 risk

This relationship is significant between dependent variables and independent variables because of sig value which equals 0.00 .

This result leads to reject $\mathrm{H} 0$ in the multivariable hypothesis (There is no significant impact for profit, size, risk and growth on book leverage ratio) and accept H1 (There is a significant impact for profit, size, risk and growth on book leverage ratio).

b) Market value-Multiple Regression Model

Regarding the market value multiple regression model, table 30 represents the summary analysis

Table 30. Market value-multi regression model summary

\begin{tabular}{|l|l|l|l|l|}
\hline Model & $\mathrm{R}$ & R Square & Adjusted R Square & Std. Error of the Estimate \\
\hline 1 & $.863^{\mathrm{a}}$ & .745 & .740 & .1623838 \\
\hline
\end{tabular}

Result in the table shows that dependent variables are related to book leverage with correlation coefficient $(\mathrm{R})$ of $(\mathrm{R}=86.3 \%)$. The coefficient of determination $\mathrm{R}$ square equals $74.5 \%$ which represents the variation in market leverage explained by variation in the independent variables. The coefficient of the equation (11) is given either in table 31 which shows that:

$\beta 0=-0.778$

$\beta 1=-1.941$

$\beta 2=0.107$

$\beta 3=0.031$

$\beta 4=0.967$

Table 31. Market value-multi regression model Coefficients ${ }^{\text {a }}$

\begin{tabular}{|l|l|l|l|l|l|l|}
\hline \multicolumn{2}{|l|}{ Model } & Unstandardized Coefficients & Standardized Coefficients & t & Sig. \\
\cline { 3 - 8 } \multicolumn{2}{|l|}{1} & B & Std. Error & Beta & & \\
\cline { 2 - 7 } & (Constant) & -.778 & .082 & & -9.452 & .000 \\
\cline { 2 - 7 } & Profit & -1.941 & .225 & -.352 & -8.609 & .000 \\
\cline { 2 - 7 } & Size & .107 & .006 & .692 & 17.435 & .000 \\
\cline { 2 - 7 } & Growth & .031 & .023 & .050 & 1.346 & .180 \\
\cline { 2 - 7 } & Risk & .967 & .229 & .169 & .000 \\
\hline
\end{tabular}


The market value multi regression model will be:

$$
\text { Marketlev }=-0.778-1.941 \text { Profit }+0.107 \text { size }+0.031 \text { growth }+0.967 \text { risk }
$$

This relationship is significant between dependent variables and independent variables because of sig value which equals 0.00 .

This result leads to reject $\mathrm{H} 0$ in the multivariable hypothesis (There is no significant impact for profit, size, risk and growth on market leverage ratio) and accept H1 (There is a significant impact for profit, size, risk and growth on market leverage ratio).

\section{Conclusions}

This study examined the determinants of capital structure in a sample of 39 Bahraini companies listed in Bahrain Bourse (stock market). First model of the research demonstrates that profitability of is one of the determinants of firms capital structure (book leverage and market leverage). The coefficient of profitability model is significantly negative, which means that firms with high level of profitability depend on auto financing rather than debt. This result is similar to the findings of (Jensen, 1986) who found that management in highly profitable firms will avoid using debt. It is aligned also with the results of Rajan \& Zingales (1995) in USA firms, Rao \& Jijo (2001); Pathak (2005); Baral (2004) in Nepal \& Mishra (2011) in Indian manufacturing companies, Meero (2015) in GCC banking sector. This result is aligned either with pecking order theory that firm will prioritize using its internal funds. Amidu (2007) in Bangladesh find a significant but positive relationship between profitability and capital structure. Same result has been found by Wahab \& Ramli (2014), Acaravci (2015) and Alani \& Alamri (2015).

The risk has a weak significant positive effect on the market leverage of the debt ratio and it has non-significant effect on book value of debt. It means risk doesn't affect significantly the capital structure of the firm of the study. This result aligned with findings of Titman \& Wessels (1988) who argue that risk (earnings volatility) doesn't appear to be related to the various measures of leverage.

The result shows that growth is not a determinant of capital structure where non-significant relationship has been detected in the study between capital structure variables and growth. This result is similar to the findings of Titman \& Wessels, (1988); Chen (2004) and Naim Nasimi (2016).

Size capital structure model shows a positive significant coefficients in both sets of debt ratio (book leverage and market leverage). This result is similar to the findings of Sapienza (2004), Khrawish \& Khraiwesh (2010). It is clear from the regression model that significance of this relationship of size with leverages is stronger with market leverage. This may be related to the positive relationship between market value and capacity of borrowing where firms with higher market value than book value have stronger borrowing capacity. Other empirical results align with these findings such as Levent \& Ersan (2012), Kumar et al. (2012), Mahvish \& Qaisar (2012), Maxwell \& Kehinde (2012), Tomak (2013), Wahab \& Ramli (2014) and Abdeljawad et al. (2014). 
For future research, more independent variables should be included in the study and consider longer period for the collected data. Similar comparative study between Bahrain and other Gulf or regional countries should give more credibility to the results of the research.

\section{References}

Abdeljawad, I., Mat-Nor, F., Ibrahim, I., \& Abdul-Rahim, R. (2013). Dynamic capital structure trade-off theory: evidence from Malaysia. International Review of Business Research Papers, 9(6), 102-110.

Abdul Wahab, R., Mohd Amin, M. S., \& Yusop, K. (2012). Determinants of capital structure of Malaysian property developers. Middle-East Journal of Scientific Research, 11(8), 1013-1021.

AbWahab, S. N. A., \& Ramli, N. A. (2014). The determinants of capital structure: an empirical investigation of Malaysian listed government linked companies. International Journal of Economics and Financial Issues, 4(4), 930-945.

Acaravci, S. K. (2015). The determinants of capital structure: evidence from the Turkish manufacturing sector. International Journal of Economics and Financial Issues, 5(1), 158.

Afza, T., \& Hussain, A. (2011). Determinants of capital structure across selected manufacturing sectors of Pakistan. International Journal of Humanities and Social Science, 19(12), 254-262.

Alani, M. K., \& Alamri, M. S. (2015). The determinants of capital structure: an empirical study of Omani listed industrial companies. Business: Theory and Practice, 16(2), 159-167.

Altunbas, Y., Carbo, S., Gardener, E. P., \& Molyneux, P. (2007). Examining the relationships between capital, risk and efficiency in European banking. European Financial Management, 13(1), 49-70. https://doi.org/10.1111/j.1468-036X.2006.00285.x

Amidu, M. (2007). Determinants of capital structure of banks in Ghana: an empirical $\begin{array}{llll}\text { approach. Baltic Journal of } & \text { Management, } & \text { 2(1), }\end{array}$ https://doi.org/10.1108/17465260710720255

Antoniou, A., Guney, Y., \& Paudyal, K. (2008). The Determinants of Capital Structure: Capital Market-Oriented Versus Bank-Oriented İnstitutions. Journal of Financial and Quantitative Analysis, 43, 59-92. https://doi.org/10.1017/S0022109000002751

Awan, A., \& Amin, M. S. (2014). Determinants of capital structure. European Journal of Accounting Auditing and Finance Research, 2(9), 22-41.

Baharuddin, N. S., Khamis, Z., Mahmood, W. M. W., \& Dollah, H. (2011). Determinants of capital structure for listed construction companies in Malaysia. Journal of Applied Finance \& Banking, 1(2), 115-132.

Bain, N., \& Band, D. (2016). Winning ways through corporate governance. Berlin: Springer.

Baral, K. J. (2004). Determinants of Capital Structure: A Case Study of Listed Companies of 
Nepal. Journal of Nepalese Business Studies, 1(1), 1-13. https://doi.org/10.3126/jnbs.v1i1.34

Barton, S. L., Hill, N. C., \& Sundaram, S. (1989). An empirical test of stakeholder theory predictions of capital structure. Financial Management, 36-44. https://doi.org/10.2307/3665696

Block, S. B., \& Hirt, G. A. (1994). Foundations of financial management. Irwin.

Booth, L., Aivazian, V., Demirguc-Kunt, A., \& Maksimovic, V. (2001). Capital structures in developing countries. The journal of finance, 56(1), 87-130. https://doi.org/10.1111/0022-1082.00320

Buferna, F., Bangassa, K., \& Hodgkinson, L. (2005). Determinants of capital structure: evidence from Libya. Working Paper, University of Liverpool, Research Paper Series, No. 2005/08.

Chakraborty, I. (2010). Capital structure in an emerging stock market: The case of India. Research in International Business and Finance, 24(3), 295-314. https://doi.org/10.1016/j.ribaf.2010.02.001

Chakraborty, I. (2013). Does capital structure depend on group affiliation? An analysis of Indian firms. Journal of Policy Modeling, 35(1), 110-120. https://doi.org/10.1016/j.jpolmod.2012.02.006

Chen, J. J. (2004). Determinants of capital structure of Chinese listed companies. Journal of Business Research, 57, 1341-1351. https://doi.org/10.1016/S0148-2963(03)00070-5

Chhapra I. U., \& Asim, M. (2012). Determinants of capital structuring: an empirical study of growth and financing behavior of firms of textile sector in Pakistan. Journal of Management and Social Sciences, 8(2), 1-10.

Chittenden, F., Hall, G., \& Hutchinson, P. (1996). Small firm growth, access to capital markets and financial structure: Review of issues and an empirical investigation. Small Business Economics, 8(1), 59-67. https://doi.org/10.1007/BF00391976

Dang, V. A. (2013). Testing capital structure theories using error correction models: evidence from the UK, France and Germany. Applied Economics, 45(2), 171-190. https://doi.org/10.1080/00036846.2011.597724

Daskalakis, N., \& Psillaki, M. (2008). Do country or firm factors explain capital structure? Evidence from SMEs in France and Greece. Applied financial economics, 18(2), 87-97. https://doi.org/10.1080/09603100601018864

Delcoure, N. (2007). The determinants of capital structure in transitional economies. International Review of Economics \& Finance, 16(3), 400-415. https://doi.org/10.1016/j.iref.2005.03.005

Demsetz, H., \& Lehn, K. (1985). The structure of corporate ownership: Causes and consequences. Journal of political economy, 93(6), 1155-1177. https://doi.org/10.1086/261354 
Fama, E. F., \& French, K. R. (2002). Testing trade-off and pecking order predictions about dividends and debt. Review of financial studies, 15(1), 1-33. https://doi.org/10.1093/rfs/15.1.1

Fauzi, F., Abdul, B., \& Idris, M. (2013). The determinants of capital structure: an empirical study of New Zealand-listed firms. Asian Journal of Finance \& Accounting, 5(2), 1-21. https://doi.org/10.5296/ajfa.v5i2.3740

Frank, M., \& Goyal, V. K. (2009). Capital structure decisions: which factors are reliably important? Financial Management, $\quad 38(1), \quad$ 1-37. https://doi.org/10.1111/j.1755-053X.2009.01026.x

Friend, I., \& Lang, L. H. (1988). An empirical test of the impact of managerial self-interest on corporate capital structure. The Journal of Finance, 43(2), 271-281. https://doi.org/10.1111/j.1540-6261.1988.tb03938.x

Ghazouani, T. (2013). The capital structure through the trade-off theory: evidence from Tunisian firm. International Journal of Economics and Financial Issues, 3(3), 625-636.

Gill, A., Biger, N., \& Mathur, N. (2011). The Effect of Capital Structure on Profitability: Evidence from the United States. International Journal of Management, 28(4), 3-15.

Handoo, A., \& Sharma, K. (2014). A study on determinants of capital structure in India. IIMB Management Review, 26, 170-182. https://doi.org/10.1016/j.iimb.2014.07.009

Hernádi, P., \& Ormos, M. (2012). Capital structure and its choice in Central and Eastern Europe. Acta Oeconomica, 62(2), 229-263. https://doi.org/10.1556/AOecon.62.2012.2.5

Hijazi, S. T., \& Tariq, Y. B. (2006). Determinants of capital structure: a case for the Pakistani cements industry. The Lahore Journal of Economics, 11(1), 63-80.

Hsia, C. C. (1981). Coherence of the modern theories of finance. Financial Review, 27-42. https://doi.org/10.1111/j.1540-6288.1981.tb01617.x

Huang, S. G. H., \& Song, F. M. (2002). The Determinants of Capital Structure: Evidence from China. Hong Kong Institute of Economics and Business Strategy, Working Paper. https://doi.org/10.2139/ssrn.320088

Huang, S. G. H., \& Song, F. M. (2006). The determinants of capital structure: evidence from China. China Economic Review, 17(1), 14-36. https://doi.org/10.1016/j.chieco.2005.02.007

Jensen, G. R., Solberg, D. P., \& Zorn, T. S. (1992). Simultaneous determination of insider ownership, debt, and dividend policies. Journal of Financial and Quantitative analysis, 27(2), 247-263. https://doi.org/10.2307/2331370

Jensen, M. C. (1986). Agency costs of free cash flow, corporate finance, and takeovers. American Economic Review, 76(2), 323-339.

Jensen, M., \& Meckling, W. (1976). Theory of the firm: Managerial Behavior, Agency Costs and Ownership Structure. Journal of Financial Economics, 3, 305-360. https://doi.org/10.1016/0304-405X(76)90026-X 
Jiajuan, L. (2010). China's Space Types of the Capital Structure and Corporate Performance of Listed Companies Empirical Research [J]. Industrial technology economy.

Jõeveer, K. (2013). What do we know about the capital structure of small firms?. Small Business Economics, 41(2), 479-501. https://doi.org/10.1007/s11187-012-9440-1

Jordan, J., Lowe, J., \& Taylor, P. (1998). Strategy and financial policy in UK small firms. Journal of Business Finance \& Accounting, 25(1-2), 1-27. https://doi.org/10.1111/1468-5957.00176

Karadeniz, E., Kandir, S. Y., Balcilar, M., \& Onal, Y. B. (2009). Determinants of capital structure: evidence from Turkish lodging companies. International Journal of Contemporary Hospitality Management, 21(5), 594-609. https://doi.org/10.1108/09596110910967827

Kayo, E. K., \& Kimura, H. (2011). Hierarchical determinants of capital structure. Journal of Banking \& Finance, 35(2), 358-371. https://doi.org/10.1016/j.jbankfin.2010.08.015

Kester, W. C. (1986). Capital and ownership structure: A comparison of United States and Japanese manufacturing corporations. Financial management, 5-16. https://doi.org/10.2307/3665273

Khrawish, H. A., \& Khraiwesh, A. H. A. (2010). The determinants of the capital structure: evidence from Jordanian industrial companies. Journal of King Abdul-Aziz University: Economic and Administration, 24(1), 173-196. https://doi.org/10.4197/eco.24-1.5

Kraus, A., \& Litzenberger, R. H. (1973). A state-preference model of optimal financial leverage. The journal of finance, 28(4), 911-922. https://doi.org/10.1111/j.1540-6261.1973.tb01415.x

Kumar, M. A. S., Dhanasekaran, M., Sandhya, S., \& Saravanan, R. (2012). Determination of financial capital structure on the insurance sector firms in India. European Journal of Social Sciences, 29(2), 288-294.

Levent, C., \& Ersan, E. (2012). The determinants of corporate debt ratio: an empirical analysis on Turkish corporations. International Research Journal of Finance and Economics, 95, 151-162.

Mahvish, S., \& Qaisar, A. M. (2012). Determinants of capital structure- a study of oil and gas sector of Pakistan. Interdisciplinary Journal of Contemporary Research in Business, 3(10), 395-400.

Maxwell, O. O., \& Kehinde, E. F. (2012). Determinants of corporate capital structure in Nigeria. International Journal of Economics and Management Sciences, 1(10), 81-96.

Meero, A. A. (2015). The Relationship between Capital Structure and Performance in Gulf Countries Banks: A Comparative Study between Islamic Banks and Conventional Banks. International Journal of Economics and Finance, 7(12), 140. https://doi.org/10.5539/ijef.v7n12p140

Michaelas, N., Chittenden, F., \& Poutziouris, P. (1999). Financial policy and capital structure 
choice in UK SMEs: Empirical evidence from company panel data. Small business economics, 12(2), 113-130. https://doi.org/10.1023/A:1008010724051

Miller, M. H. (1977). Debt and Taxes. The Journal of Finance, 32, 261-76.

Mishra, C. S. (2011). Determinants of Capital Structure- A Study of Manufacturing Sector PSUs in India. International Conference of Financial Management and Economics, 11.

Mishra, C. S., \& McConaughy, D. L. (1999). Founding family control and capital structure: The risk of loss of control and the aversion to debt. Entrepreneurship theory and practice, 23, 53-64.

Modigliani, F., \& Miller, M. H. (1958). The cost of capital, corporation finance and the theory of investment. The American economic review, 261-297.

Modigliani, F., \& Miller, M. H. (1963). Corporate income taxes and the cost of capital: a correction. The American economic review, 433-443.

Mokhova, N., \& Zinecker, M. (2013). The determinants of capital structure: the evidence from the European Union. ACTA Universities Agriculture Et Silviculture Mendelianae Brunesis, LXI(7), 2533-2546. https://doi.org/10.11118/actaun201361072533

Myers, S. (1984). The capital structure puzzle. Journal of Finance, 39(3), 575-592. https://doi.org/10.2307/2327916

Myers, S. C. (1977). Determinants of corporate borrowing. Journal of financial economics, 5(2), 147-175. https://doi.org/10.1016/0304-405X(77)90015-0

Myers, S. C., \& Majluf, N. S. (1984). Corporate financing and investment decisions when firms have information that investors do not have. Journal of financial economics, 13(2), 187-221. https://doi.org/10.1016/0304-405X(84)90023-0

Naim Nasimi, R. (2016). Determinants of Capital Structure (An Empirical Evidence, US). Global Journal of Management and Business Research, 16(4).

Pahuja, A., \& Sahi, A. (2012). Factors affecting capital structure decisions: empirical evidence from selected Indian firms. Financial Industrial \& Management Research, 1(3), 77-86.

Pathak, J. (2005). What Determines Capital Structure of Listed Firms in India? Some Empirical Evidences from the Indian Capital Market. Social Science and Review Network.

Qayyum, S. (2013). Determinants of capital structure: an empirical study of cement industry of Pakistan. Interdisciplinary Journal of Contemporary Research in Business, 24(11), 784-795.

Rajan, R. G., \& Zingales, L. (1995). What do we know about capital structure? Some evidence from international data. The journal of Finance, 50(5), 1421-1460. https://doi.org/10.1111/j.1540-6261.1995.tb05184.x

Rao, S. N., \& Jijo, L. P. J. (2001). Determinants of Capital Structure in India: A Comparative 


\section{Macrothink}

Study of Pre-and-Post Liberalization Regime. The Journal of Management and Accounting Research.

Rathinasamy, R., Krishnaswamy, C., \& Mantripragada, K. (2000). Capital Structure and product market interaction: an international perspective. Global Business and Finance Review, 5(2), 51-66.

Sapienza, P. (2004). The effects of government ownership on bank lending. Journal of financial economics, 72(2), 357-384. https://doi.org/10.1016/j.jfineco.2002.10.002

Sbeiti, W. (2010). The determinants of capital structure: evidence from the GCC countries. International Research Journal of Finance and Economics, 47, 54-79.

Shah, A., \& Khan, S. (2007). Determinants of capital structure: Evidence from Pakistani panel data. International review of business research papers, 3(4), 265-282.

Sibilkov, V. (2009). Asset liquidity and capital structure. Journal of Financial and Quantitative Analysis, 44(5), 1173-1196. https://doi.org/10.1017/S0022109009990354

Smith, C. W., \& Watts, R. L. (1992). The investment opportunity set and corporate financing, dividend, and compensation policies. Journal of financial Economics, 32(3), 263-292. https://doi.org/10.1016/0304-405X(92)90029-W

Strebulaev, I. A. (2007). Do tests of capital structure theory mean what they say?. The Journal of Finance, 62(4), 1747-1787. https://doi.org/10.1111/j.1540-6261.2007.01256.x

Stulz, R. (1990). Managerial discretion and optimal financing policies. Journal of financial Economics, 26(1), 3-27. https://doi.org/10.1016/0304-405X(90)90011-N

Teker, D., Tasseven, O., \& Tukel, A. (2009). Determinants of capital structure for Turkish firms: A panel dat. International Research Journal of Finance and Economics, 29, 179-187.

Titman, S., \&Wessels, R. (1988). The Determinant of Capital Structure Choice. Journal of Financial, 43(1), 1-19. https://doi.org/10.1111/j.1540-6261.1988.tb02585.x

Tomak, S. (2013). The impact of overconfidence on capital structure in Turkey. International Journal of Economics and Financial Issues, 3(2), 512-518.

\section{Copyright Disclaimer}

Copyright for this article is retained by the author(s), with first publication rights granted to the journal.

This is an open-access article distributed under the terms and conditions of the Creative Commons Attribution license (http://creativecommons.org/licenses/by/3.0/). 